\title{
Conjugated linoleic acids influence fatty acid metabolism in ovine ruminal epithelial cells
}

\author{
F. Masur, ${ }^{* 1}$ F. Benesch, ${ }^{*}$ H. Pfannkuche, ${ }^{*}$ H. Fuhrmann, $†$ and G. Gäbel ${ }^{*}$ \\ *Institute of Veterinary Physiology, and \\ †Institute of Physiological Chemistry, Faculty of Veterinary Medicine, University of Leipzig, Leipzig, 04103, Germany
}

\begin{abstract}
Conjugated linoleic acids (CLA), particularly cis9,trans-11 (c9t11) and trans-10,cis-12 (t10c12), are used as feed additives to adapt to constantly increasing demands on the performance of lactating cows. Under these feeding conditions, the rumen wall, and the rumen epithelial cells (REC) in particular, are directly exposed to high amounts of CLA. This study determined the effect of CLA on the fatty acid (FA) metabolism of REC and expression of genes known to be modulated by FA. Cultured REC were incubated with c9t11, t10c12, and the structurally similar FA linoleic acid (LA), oleic acid (OA), and trans-vaccenic acid (TVA) for $48 \mathrm{~h}$ at a concentration of $100 \mu M$. Cellular FA levels were determined by gas chromatography. Messenger RNA expression levels of stearoyl-CoA desaturase $(S C D)$ and monocarboxylate transporter $(M C T) 1$ and 4 were quantified by reverse transcription-quantitative PCR. Fatty acid evaluation revealed significant effects of CLA, LA, OA, and TVA on the amount of FA metabolites of $\beta$-oxidation and elongation and of metabolites related to desaturation by SCD. The observed changes in FA content point (among others) to the ability of REC to synthesize c9t11 from TVA endogenously. The mRNA expression levels of $S C D$ identified a decrease after CLA, LA, OA, or TVA treatment. In line with the changes in mRNA expression, we found reduced amounts of $\mathrm{C} 16: 1 \mathrm{n}-7$ cis- 9 and $\mathrm{C} 18: 1 \mathrm{n}-9$ cis- 9 , the main products of SCD. The expression of MCT1 mRNA increased after c9t11 and t10c12 treatment, and CLA c9t11 induced an upregulation of MCT4. Application of peroxisome proliferator-activated receptor (PPAR) $\alpha$ antagonist suggested that activation of PPAR $\alpha$ is involved in the changes of MCT1, MCT4, and SCD mRNA expression induced by c9t11. Participation of PPAR $\gamma$ in the changes of MCT1 and SCD mRNA expression was shown by the application of the respective
\end{abstract}

Received July 1, 2015.

Accepted December 11, 2015.

${ }^{1}$ Corresponding author: franziska.masur@vetmed.uni-leipzig.de antagonist. The study demonstrates that exposure to CLA affects both FA metabolism and regulatory pathways within REC.

Key words: conjugated linoleic acid, rumen epithelium, stearoyl-CoA desaturase, monocarboxylate transporter, peroxisome proliferator-activated receptor

\section{INTRODUCTION}

Conjugated linoleic acids are known to have a wide range of physiological effects (Bhattacharya et al., 2006). They affect energy metabolism not only in humans (Salas-Salvadó et al., 2006) but also in ruminants (Odens et al., 2007). Thus, CLA have gained importance as feed additives in ruminants and, in particular, in lactating cows. As reviewed by Bauman et al. (2008), CLA trans-10,cis-12 (t10c12) in particular reduces milk fat synthesis in dairy cows, stabilizing the energy balance of the animal (Odens et al., 2007). The CLA cis-9,trans-11 (c9t11) isomer has been intensively studied because it is the predominant CLA in dairy products (Chin et al., 1992; Parodi, 1997) due to endogenous synthesis of this CLA (Corl et al., 2001). Commercially available mixtures of CLA, offered as feed additives for cows, mainly contain rumen-protected c9t11 and t10c12, and are aimed at initiating milk fat depression and thus stabilizing the health status of the cow at least at the onset of lactation. However, the study of Pappritz et al. (2011) revealed that only 5 to $40 \%$ of rumen-protected CLA reach the duodenum, depending on the protection method. Thus, it must be assumed that a large part of the CLA taken up orally are already released in the rumen. When CLA are released into the rumen fluid, their subsequent reduction (biohydrogenation) to trans-vaccenic acid (TVA; C18:1 trans-11) and stearic acid (C18:0; Harfoot and Hazlewood, 1997) may last up to $24 \mathrm{~h}$ (Troegeler-Meynadier et al., 2006). Thus, under these feeding conditions, the rumen epithelium may be exposed to a high CLA concentration, which may lead not only to CLA accumulation within the epithelium or release of CLA metabolization products but also to functional changes induced by CLA or their metabolites. 
To date, CLA accumulation and metabolization have been described in human vascular endothelial cells and smooth muscle cells (Müller et al., 2005; Ringseis et al., 2006; Eder and Ringseis, 2010). Regarding functional effects after CLA exposure, changes in stearoyl-CoA desaturase (SCD) status have been frequently described (Choi et al., 2001, 2002; Smith et al., 2002). In the rumen epithelium, SCD has not been detected to date. Stearoyl-CoA desaturase catalyzes the conversion of TVA to CLA (Griinari et al., 2000). Therefore, if the rumen epithelium could produce CLA endogenously from TVA catalyzed by SCD, this process would increase the amount of CLA that accumulates in rumen epithelial cells (REC) when CLA are added to the food. Presuming a modulation of SCD by CLA, accumulation of CLA in REC may also affect the amount of other products catalyzed by SCD.

We assumed that the accumulation of CLA might also have an effect on monocarboxylate transporter (MCT). In the rumen epithelium, the MCT1 isoform has been detected at the molecular and protein levels and has been shown to play a central role in mediating transruminal fluxes of short-chain fatty acids, including acetate, ketone bodies, and lactate (Müller et al., 2002; Graham et al., 2007; Dengler et al., 2014). Furthermore, activation of the peroxisome proliferatoractivated receptor (PPAR) \& pathway was demonstrated to lead to the effective upregulation of the MCT1 isoform in REC (König et al., 2008; Benesch et al., 2014). In turn, PPAR $\alpha$ is modulated by CLA, with c9t11 being the most active isomer (Moya-Camarena et al., 1999; Benjamin et al., 2005). In addition to the MCT1 isoform, the MCT4 isoform is also present in the rumen (Kirat et al., 2007). Although MCT4 regulatory pathways are not completely understood, research suggests that PPAR may play a role (Benesch et al., 2014).

Our objective was to expose cultured REC to CLA isoforms to better understand whether and how CLA accumulate in and exert effects on the cells. Cells were further exposed to linoleic acid (LA), oleic acid (OA), or TVA to distinguish between the effects of CLA and fatty acids (FA), which are structurally similar FA or precursors of endogenous CLA synthesis (Griinari et al., 2000). A further aim of our study was to investigate whether REC themselves express SCD and thus have the ability to desaturate the appropriate substrates, TVA in particular. Expression of SCD mRNA was determined by reverse-transcription quantitative PCR (RT-qPCR) to test if it can be influenced by CLA, LA, OA, or TVA. Monocarboxylate transporter 1 and MCT4 were seen as potential targets of CLA treatment and were therefore examined in detail. Finally, we attempted to elucidate the putative regulatory pathway of CLA on SCD, MCT1, and MCT4 through the application of PPAR $\alpha$ and PPAR $\gamma$ antagonists.

\section{MATERIALS AND METHODS}

\section{Animals}

Female sheep $(<1$ yr) were fed with grass hay and water ad libitum for at least 2 wk. The animals were killed by captive-bolt stunning and subsequent exsanguination. These experiments were in accordance with German legislation on the protection of animals and were reported to the Landesdirektion Leipzig as $\mathrm{T}$ 88/13. After euthanasia, the abdomen was opened, and the atrium ruminis was excised and subjected to the cell isolation procedure.

\section{Cell Culture and Treatment Procedure}

Cultivation of REC followed the procedure described by Müller et al. (2000) and Benesch et al. (2014). Because all experiments were conducted on subcultured cells obtained from primarily isolated cells, the cells had to be isolated and cultured anew from each sheep slaughtered.

For that purpose, pieces of the excised atrium ruminis were kept on ice in $\mathrm{Ca}^{2+}$ - and $\mathrm{Mg}^{2+}$-free Dulbecco's PBS supplemented with $400 \mathrm{U} / \mathrm{mL}$ penicillin and 100 $\mathrm{U} / \mathrm{mL}$ nystatin for $1 \mathrm{~h}$. Thereafter, ruminal papillae were removed and subjected to fractional trypsinization as described by Gálfi et al. (1981). Division-active cells were found in fractions 3 and 4 ( $1 \mathrm{~h}$ of enzyme digestion per fraction). Isolated cells of those fractions were suspended in medium 199 containing $15 \%$ fetal bovine serum (FBS), $20 \mathrm{~m} M$ HEPES, $50 \mu \mathrm{g} / \mathrm{mL}$ gentamicin, and $2 \mathrm{mM}$ L-glutamine and seeded at a density of $10^{5}$ cells $/ \mathrm{cm}^{2}$ in cell culture flasks $\left(75 \mathrm{~cm}^{2}\right.$; Greiner Bio One, Frickenhausen, Germany). Incubation proceeded in a humidified $5 \% \mathrm{CO}_{2}$ air atmosphere at $37^{\circ} \mathrm{C}$. Forty-eight hours after seeding, medium 199 was replaced with minimum essential Eagle's nutrient medium supplemented with 10\% FBS, $20 \mathrm{~m} M$ HEPES, $50 \mu \mathrm{g} / \mathrm{mL}$ gentamicin, and $2 \mathrm{~m} M$ L-glutamine. Six to 9 d after seeding, primary cultured cells were subcultured to obtain consistent cell densities for mRNA and GC analysis. After detaching with trypsin-EDTA, cells were resuspended and seeded (seeding density: $2-3 \times$ $10^{4}$ cells $\left./ \mathrm{cm}^{2}\right)$ in cell culture flasks $\left(75 \mathrm{~cm}^{2}\right.$; Greiner Bio One) for GC analysis, 12-well plates coated with collagen type I (Greiner Bio One) for mRNA analysis, and collagen type I-coated coverslips for immunocytochemical staining. The immunocytochemical staining was performed about $2 \mathrm{~d}$ after seeding using mouse- 
anti-cytokeratin-5 antibody (BM6001P, polyclonal, dilution 1:100; Acris Antibodies, San Diego, CA) and goat-anti-vimentin antibody (sc-7557, polyclonal, dilution 1:300; Santa Cruz Biotechnology, Santa Cruz, CA) to evaluate the suitability of the cell culture for the experiments. If cell cultures showed more than $\sim 20 \%$ mesenchymal cells on the coverslips, all flasks and well plates from that isolation were discarded. If cell cultures consisted mainly of epithelial cells and cells were $\sim 80 \%$ confluent, flasks and wells were treated with CLA, LA, OA, or TVA. All FA used were dissolved in ethanol to generate stock solutions at concentrations of $35.7 \mathrm{mM}$ $(10 \mathrm{mg} / \mathrm{mL})$ for CLA and LA and $35.4 \mathrm{mM}(10 \mathrm{mg} /$ $\mathrm{mL}$ ) for OA and TVA, which were added to low-serum medium containing minimum essential Eagle's nutrient medium supplemented with 5\% FBS, $20 \mathrm{~m} M$ HEPES, and $2 \mathrm{mM}$ L-glutamine. The final concentration of FA in the cell culture medium on 12-well plates was 100 $\mu M$. In cell culture flasks, the final concentration was $100 \mu M$. Both CLA and TVA were additionally tested at a final concentration of $200 \mu M$ in flasks. By MTT [3-(4,5-dimethylthiazol-2-yl)-2,5-diphenyltetrazolium bromide] assay, all supplemented FA were proven to be noncytotoxic. Rumen epithelial cells treated with the appropriate volume of ethanol were used as controls. Exposure to FA or ethanol lasted for $48 \mathrm{~h}$. For experiments on PPAR $\alpha$ and PPAR $\gamma$ inhibition, cells were treated with $10 \mu M$ GW 6471, a selective PPAR $\alpha$ antagonist (Xu et al., 2002), or with $10 \mu M$ GW 9662, a selective PPAR $\gamma$ antagonist (Leesnitzer et al., 2002) $4 \mathrm{~h}$ before treatment with $100 \mu M \mathrm{c} 9 \mathrm{t} 11$ for $48 \mathrm{~h}$. All chemicals were obtained from Sigma-Aldrich (Munich, Germany) and PAA (Pasching, Austria) if not otherwise stated; CLA c9t11, t10c12, LA, TVA, and OA were obtained from Sigma-Aldrich with a purity of $\geq 96.0 \%$ (HPLC grade) for CLA and $\geq 99.0 \%$ (GC grade) for LA, TVA, and OA.

\section{FA Extraction and Methylation}

For FA analysis, subcultured cells obtained from 5 sheep were used for each experimental series (i.e., N $=5$ biological replicates). Each treatment was tested once per cell culture per sheep (i.e., $\mathrm{n}=1$ technical replicate). Cells were cultured in culture flasks (75 $\mathrm{cm}^{2}$; Greiner Bio One). After exposing the cells to the treatments described above, approximately 1 to $10 \times$ $10^{6}$ cells per flask and treatment were detached by trypsinization and pelleted by centrifugation $(200 \times$ $g$ ). Cells were washed by resuspending the cell pellet in PBS. To discard the supernatant, the cells were centrifuged again $(200 \times g)$. The cell pellet was lysed with $1 \mathrm{~mL}$ of twice-distilled water and freeze-dried overnight before extraction and methylation. We used a combined one-step extraction and esterification method as described by Sönnichsen and Müller (1999). The samples were treated with $0.5 \mathrm{~mL}$ of methanolic $\mathrm{HCl}(3 \mathrm{M}), 0.25 \mathrm{~mL}$ of $n$-hexane, and $0.5 \mathrm{~mL}$ of an internal standard (0.8 mg of di-C17-phosphatidylcholine in $1 \mathrm{~mL}$ of methanol with $0.2 \%$ butylhydroxytoluol as an antioxidant) as previously described by Seidel et al. (2005). The reaction proceeded in a water bath at $85^{\circ} \mathrm{C}$ for $30 \mathrm{~min}$. After cooling to room temperature, $0.5 \mathrm{~mL}$ of hexane was added to extract FAME as well as $1 \mathrm{~mL}$ of twice-distilled water for phase separation. The mixture was shaken $(2,700 \mathrm{rpm})$ for $1 \mathrm{~min}$. After centrifugation $(3,500 \times g)$ for $10 \mathrm{~min}$ at $4^{\circ} \mathrm{C}$, the upper hexane phase was separated and transferred to a new tube. The samples were evaporated with a gentle nitrogen flow at $37^{\circ} \mathrm{C}$ to dryness and dissolved in 0.06 $\mathrm{mL}$ of hexane.

\section{GC Analysis}

Separation and quantification of FAME were carried out using a Varian gas chromatograph 3800 equipped with a flame-ionization detector and with a $30-\mathrm{m}$ fusedsilica capillary column (Omegawax 320 GC Capillary Column, Supelco 24152) from Sigma-Aldrich. Helium 5.0 (purity: $\geq 99.999 \%$ ) was used as carrier gas at a flow rate of $1.5 \mathrm{~mL} / \mathrm{min}$. The oven temperature was kept at $200^{\circ} \mathrm{C}$ isothermally for $40 \mathrm{~min}$. The injector and detector temperatures were set at $250^{\circ} \mathrm{C}$. Aliquots of $1 \mu \mathrm{L}$ were injected on column with a split ratio of 1:50. After $1 \mathrm{~min}$, the split ratio was set to $1: 100$ for baseline optimization. After $20 \mathrm{~min}$ and $30 \mathrm{~s}$, the split ratio was set to 1:3 (gas saver). Fatty acids were identified by comparing their retention time and mass spectra to FAME reference compounds recorded during this study. The following reference standards were used: Supelco 37 Component FAME Mix, PUFA No. 3, linoleic acid methyl ester mix, cis/trans and Omegawax Column Test Mix from Supelco (Bellefonte, PA); and Fim-Fame-6 quantitative mixture from Matreya LLC (State College, PA). In addition, GC-MS analysis was carried out using the identical chromatographic system as described above. The MS was operated in fullscan $(m / z=50-500)$ mode using electron ionization. The acquired data were evaluated manually and by automatic deconvolution using AMDIS (National Institute of Standards and Technology, Gaithersburg, MD). The AMDIS settings were simple mode; peak subtraction, 2 ; resolution, high; sensitivity, very high; and shape requirements, low. In both cases, identification was achieved by the NIST11 reference library (National Institute of Standards and Technology). 
The Omegawax 320 column cannot separate cis- and trans-MUFA of the same chain length. Furthermore, n-9 and n-7 elute close to each other, leading to interfering FA. Consequently, C16:1n-9 was not separated from C16:1n-7 trans-9 after TVA treatment.

For quantification, response factors were determined from calibration curves of the Fim-Fame-6 quantitative mixture and pure compounds. For those FA not available as pure compounds, response factors were estimated from the nearest calibrated peak. The amount of each FA detected by GC was related to total protein. The total protein of each sample was determined using the bicinchoninic acid (BCA) assay (Smith et al., 1985). Data were thus expressed as medians (nmol) of each FA related to $1 \mathrm{mg}$ of total protein.

\section{$R T-q P C R$}

For RT-qPCR, subcultured cells obtained from 6 sheep were used for each experimental series (i.e., $\mathrm{N}$ $=6$ biological replicates). Each treatment was tested 3 times per cell culture per sheep (i.e., $\mathrm{N}=3$ technical replicates). Cells were cultured on 12-well plates. After exposing the cells to the treatments described above, isolation of total RNA was performed with an RNeasy Micro kit according to the manufacturer's protocol. To assess nucleic acid concentration and sample purity, the samples were diluted in $\mathrm{H}_{2} \mathrm{O}$ and the absorbance at 230, 260, 280, and $320 \mathrm{~nm}$ was measured spectrophotometrically (Biophotometer; Eppendorf AG, WesselingBerzdorf, Germany). Each sample was checked for RNA degradation by electrophoresis in 1\% agarose gels. Reverse transcription was performed with the GoScript Reverse Transcription System (Promega, Mannheim, Germany). Total RNA $(1 \mu \mathrm{g})$ and oligo $(\mathrm{dT})_{18}$ primer $(1 \mu \mathrm{L})$ were dissolved in $\mathrm{H}_{2} \mathrm{O}$ to a total volume of $5 \mu \mathrm{L}$ and incubated at $70^{\circ} \mathrm{C}$ for $5 \mathrm{~min}$, immediately chilled on ice for $5 \mathrm{~min}$, and centrifuged for $10 \mathrm{~s}$. Thereafter, $4 \mu \mathrm{L}$ of $5 \times$ reaction buffer, $1.5 \mathrm{mM} \mathrm{MgCl}, 20 \mathrm{U}$ of ribonuclease inhibitor, $1 \mu \mathrm{L}$ of $\mathrm{dNTP}$ mix, and $1 \mu \mathrm{L}$ of reverse transcriptase were added to a total reaction volume of $20 \mu \mathrm{L}$. This mixture was incubated at $25^{\circ} \mathrm{C}$ for $5 \mathrm{~min}, 42^{\circ} \mathrm{C}$ for $1 \mathrm{~h}$ and then for $5 \mathrm{~min}$ at $70^{\circ} \mathrm{C}$ to inactivate the reverse transcriptase. The cDNA was stored at $-20^{\circ} \mathrm{C}$ until further use.

For RT-qPCR, primers (Supplemental Table S1; http://dx.doi.org/10.3168/jds.2015-10042) were designed based on sequences in the GenBank database using primer-BLAST tool (Ye et al., 2012). All primers were synthesized by Eurofins MWG (Ebersberg, Germany). The PCR products of the synthesized primer pairs were checked for specificity using agarose gel electrophoresis combined with sequencing. The obtained sequences were validated against the corresponding
National Center for Biotechnology Information (NCBI) database entries (Altschul et al., 1997). Reverse transcription-qPCR was performed using SYBR Green I and the Rotor-Gene 6000 system (Corbett Research, Mortlake, NSW, Australia). The SensiMix SYBR NoROX Kit (Bioline, Luckenwalde, Germany) was used according to the manufacturer's protocol, with a final reaction volume of $20 \mu \mathrm{L}$ and a primer concentration of $112 \mathrm{n} M$. Each RT-qPCR run contained a no-template control with DNase-free water instead of cDNA. Melting curve analysis was performed at the end of each RT-qPCR reaction to confirm the amplification specificity. The reaction for each sample was performed in duplicate. Comparative quantitation analysis was performed using the Rotor-Gene Series Software 1.7 (Corbett Research) to determine the takeoff point and the amplification rate of each RT-qPCR reaction. Expression ratios were calculated using the relative expression software tool (REST2009, RG-Mode; Pfaffl et al., 2002) including a correction for reaction-specific amplification rate and normalization against the expression level of 2 averaged (geometric mean) reference genes, GAPDH and $\mathrm{Na}^{+} / \mathrm{K}^{+}$-ATPase subunit $\alpha-1$. The mean takeoff point and the mean amplification rate of control samples were used as calibrator sample. To present changes in the expression level of differently treated cells as mean fold changes compared with the control or to the c9t11 treatment, the control value or the value of the c9t11-treated cells was set to 1 . Based on the takeoff point values, the expression of both reference genes was not different between the control and treated cells, and thus, between the control tissue and treated tissue samples, respectively.

\section{FA Enzyme Indices}

Fatty acid enzyme indices were calculated according to Peter et al. (2009) as FA product-to-precursor ratios of the individual FA amounts (nmol/mg of total protein) to indirectly determine the enzyme status of REC in combination with changes in mRNA expression. The SCD desaturation index was assessed as the ratio of C16:1n-7 cis-9 to C16:0 (SCDI-16) and C18:1n-9 cis-9 to C18:0 (SCDI-18). The FA elongation state was estimated from the elongation index (EI) as calculated by the ratio of C18:0 to C16:0 (Cedernaes et al., 2013). The SCDI-18 index was not determined for OA treatment because OA itself is part of the SCDI-18 calculation, which leads to biased results within the interpretation of desaturation rate. As described in the GC Analysis section, it was not possible to determine the amount of C16:1n-7 after TVA treatment. Therefore, SCDI-16 could not be calculated for TVA supplementation. 


\section{Statistical Analysis}

Statistical analysis was conducted based on biological replicates $(\mathrm{N})$. Values obtained in the various technical replicates (n) were averaged. Data of biological replicates obtained by GC (Tables 1-3) differed from the normal distribution (Shapiro-Wilk test) and did not show equal variances (Levene's statistic) within the groups. Therefore, nonparametric tests were used to compare FA compositions after different FA treatments (Tables 1-3). Hence, the amounts of each FA were expressed as the median [quartile (Q)1, Q3], and the Kruskal-Wallis test was performed. For those FA that showed statistically significant differences after different FA treatments in the Kruskal-Wallis test $(P$ $<0.05$ ), the Mann-Whitney U-test was computed as a post hoc test for comparison of the treated groups versus control. To counteract the problem of multiple comparisons, Bonferroni correction was conducted. Therefore, differences with $P<0.0125$ (Table 1) were considered significant when both CLA isomers with supplementation of 100 and $200 \mu M$ each were compared with the control. For comparison of LA and OA with their control as well as for TVA with 100 and $200 \mu M$ versus control, $P<0.025$ (Tables 2 and 3 ) was considered significant. Indices were considered normally distributed and analyzed by one-way ANOVA. For significant effects $(P<0.05)$, we proceeded with the Tukey post hoc test to find significant group differences. Statistical analysis was conducted with IBM SPSS statistics software (version 20 for Windows; IBM Corp., Armonk, NY).

Due to the nested design of the RT-qPCR analysis, the resulting biological variability and the technical noise at several "levels" of the experimental design was taken into account (Kitchen et al., 2010). To minimize the confounding variance and to accurately resolve the treatment effect based on biological replicates, we used multilevel regression analysis (Hox, 2010; Kitchen et al., 2010) for RT-qPCR analysis. The independent variable in each regression was the respective FA treatment. The dependent variable was always the relative mRNA expression ( $\log _{2}$ transformed). All analyses were conducted using the software $\mathrm{R}$ and the lmer4 package (Bates et al., 2012).

\section{RESULTS}

\section{Effects of CLA, LA, OA, and TVA on the FA Composition of REC}

Changes in the amounts of the individual FA detected in REC both reflected the FA supplementation as well as the metabolization of supplemented FA. Thus, each supplemented FA resulted in a corresponding increase of the amount in REC. Likewise, the amounts of the metabolites derived from the respective FA increased. Tables 1-3 represent the FA composition of REC exposed to CLA, LA, OA, and TVA for $48 \mathrm{~h}$ compared with untreated cells.

To evaluate the extent of accumulation of the supplemented FA in the cells compared with control, we summed the amounts of the metabolites detected and the amounts of the corresponding original FA. The corresponding metabolites were identified by the significant increase after the individual FA supplementation.

We detected $23 \mathrm{nmol} / \mathrm{mg}$ of total protein of $\Sigma$ CLA + metabolites in control REC, whereas addition of 100 or $200 \mu M$ c9t11 led to 5.4- and 11.8-fold increases, respectively, of the amount of $\Sigma$ CLA + metabolites. The addition of CLA t10c12 to the medium at 100 or $200 \mu M$ increased $\Sigma$ CLA + metabolites by 9.6 - and 20.1-fold, respectively.

When calculating the accumulation of TVA and its metabolites compared with control (Table 3), we summed not only the products of elongation and $\beta$-oxidation but also those of desaturation (as outlined in the section Confirmation of SCD Functionality in REC). Treatment with TVA at 100 or $200 \mu M$ increased $\Sigma$ TVA + metabolites by 10.2- and 17.3-fold, respectively, compared with control cells. The addition of LA to the cell culture medium resulted in a 12.4fold increase of $\Sigma \mathrm{LA}+$ metabolites, whereas exposure of the cells to OA led only to a small increase (1.8-fold) of $\Sigma \mathrm{OA}+$ metabolites. Beside changes in the supplemented FA and their metabolites, we also studied general changes of the FA composition of REC. The amount of $\Sigma$ SFA in REC, which included evennumbered SFA ranging from C14:0 to C24:0, was not altered after exposure of REC to c9t11 and t10c12, LA, or OA. The TVA treatment tended to reduce $\Sigma$ SFA $(P=0.075)$; this reduction was mainly due to a strong and significant reduction of the amount of C18:0 $(P$ $=0.01$; Table 3 ). To calculate $\Sigma$ MUFA, we summed the $\Sigma$ cis n-9 MUFA and the 4 FA as described in the Table 3 footnotes; $\Sigma$ MUFA could not be calculated for TVA treatment for analytical reasons, as described in the GC Analysis section. Supplementation with CLA as well as LA and OA strongly affected $\Sigma$ MUFA. Treatment with both CLA isomers and LA decreased $\Sigma$ MUFA of REC primarily due to reductions in amounts of C16:1n-7 cis-9 and C18:1n-9 cis-9 (OA). The TVA treatment also decreased the amount of C18:1n-9 cis-9; therefore, we expected that $\Sigma$ MUFA was as strongly affected after TVA treatment as after other FA treat- 
MASUR ET AL.

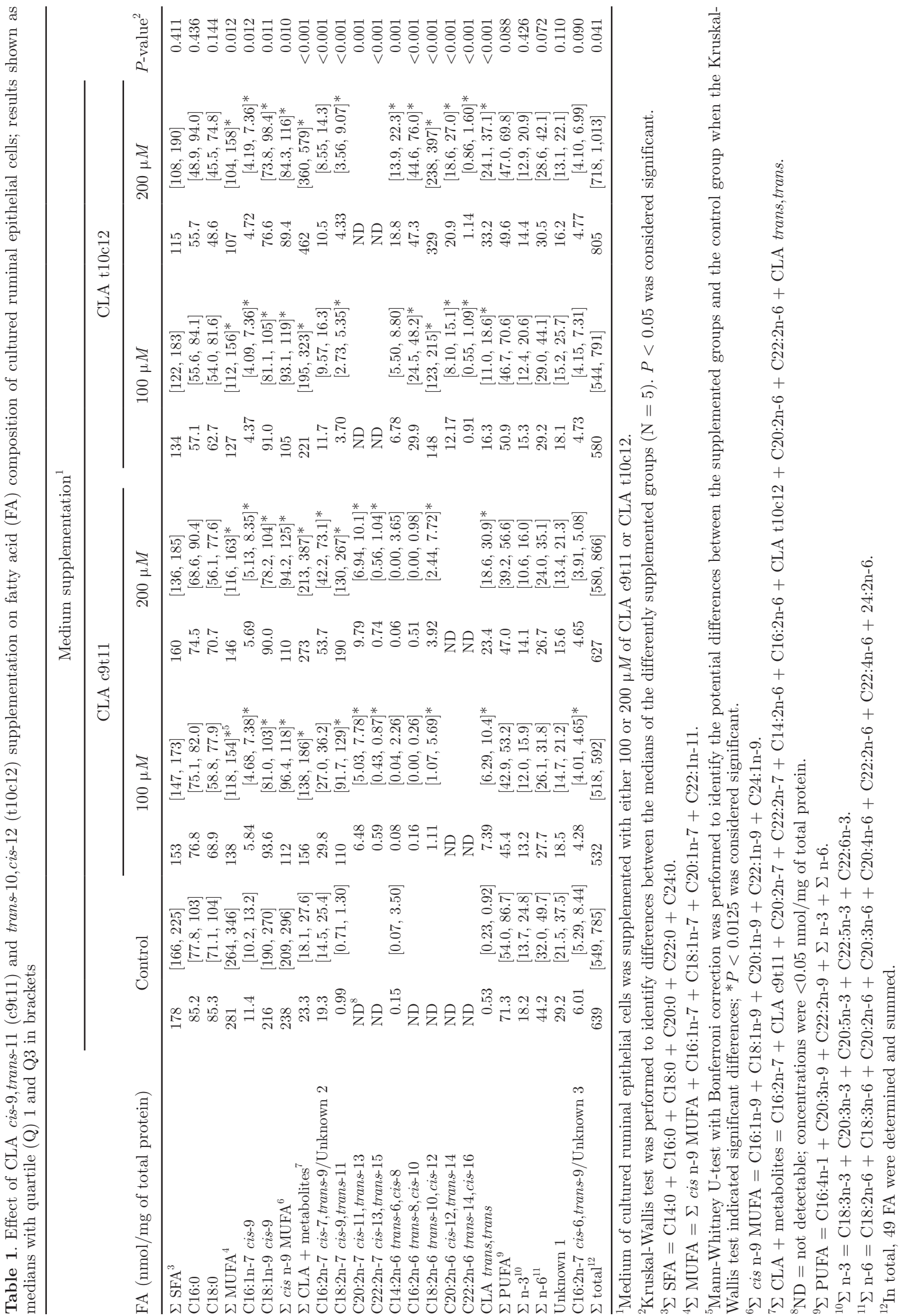


ments, even though $\Sigma$ MUFA was not determined. In contrast to CLA, LA, and TVA treatments, $\Sigma$ MUFA increased $(P=0.002)$ in OA-treated cells because the added FA and their metabolites are themselves MUFA.

The sum of PUFA was calculated as the sum of $\Sigma$ n-3, $\Sigma$ n- 6 , and the 3 other FA described in the table footnotes. Due to the addition of LA, $\Sigma$ PUFA increased in the respectively treated cells $(P=0.008)$. None of the other treatments affected $\Sigma$ PUFA.

In addition to changes in the amounts of clearly defined FA, we detected changes in amounts of an FA whose structure we could not definitely determine (FA Unknown 1, Unknown 2, and Unknown 3, see Supple- mental Materials and Tables S2, S3, and S4; http:// dx.doi.org/10.3168/jds.2015-10042).

Although changes were evident in the amounts of the individual FA and FA groups calculated, the total amount of FA ( $\Sigma$ total) was either not changed or only slightly changed (Tables 1-3). As shown in Table 3, only treatment with TVA at $200 \mu M$ led to an increase of $\Sigma$ total in $\operatorname{REC~}(P=0.018)$.

\section{Confirmation of SCD Functionality in REC}

Stearoyl-CoA desaturase could be detected on the mRNA level. The suggestion of an active SCD can be

Table 2. Effect of linoleic and oleic acid supplementation on fatty acid (FA) composition of cultured ruminal epithelial cells; results shown as medians with quartile (Q) 1 and Q3 in brackets

Medium supplementation

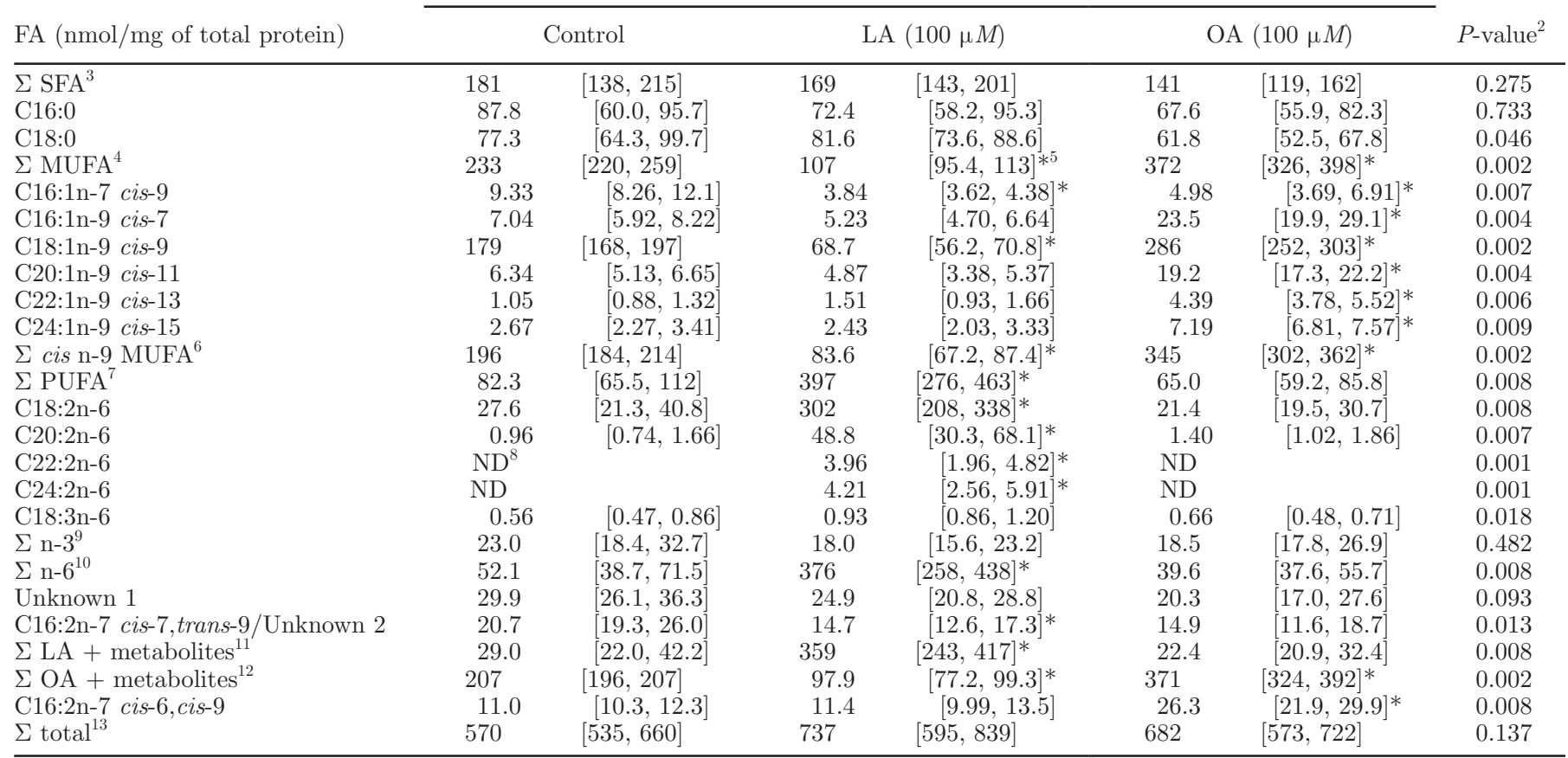

${ }^{1}$ Medium of cultured ruminal epithelial cells was supplemented with $100 \mu M$ linoleic acid (LA) or oleic acid (OA).

${ }^{2}$ Kruskal-Wallis test was performed to identify differences between the medians of the differently supplemented groups $(\mathrm{N}=5$ ); $P<0.05$ was considered significant.

${ }^{3} \Sigma \mathrm{SFA}=\mathrm{C} 14: 0+\mathrm{C} 16: 0+\mathrm{C} 18: 0+\mathrm{C} 20: 0+\mathrm{C} 22: 0+\mathrm{C} 24: 0$.

${ }^{4} \Sigma$ MUFA $=\Sigma$ cis n-9 MUFA + C16:1n-7 + C18:1n-7 + C20:1n-7 + C22:1n-11.

${ }^{5}$ Mann-Whitney U-test with Bonferroni correction was performed to identify the potential differences between the supplemented groups and the control group when the Kruskal-Wallis test indicated significant differences; ${ }^{*} P<0.025$ was considered significant.

${ }^{6} \Sigma$ cis n-9 MUFA $=16: 1 \mathrm{n}-9+18: 1 \mathrm{n}-9+20: 1 \mathrm{n}-9+22: 1 \mathrm{n}-9+24: 1 \mathrm{n}-9$.

${ }^{7} \Sigma$ PUFA $=$ C16:4n-1 + C20:3n-9 + C22:2n-9 + $\Sigma$ n-3 + $\Sigma$ n- 6.

${ }^{8} \mathrm{ND}=$ not detectable; concentrations were $<0.05 \mathrm{nmol} / \mathrm{mg}$ of total protein.

${ }^{9} \Sigma \mathrm{n}-3=\mathrm{C} 18: 3 \mathrm{n}-3+\mathrm{C} 20: 3 \mathrm{n}-3+\mathrm{C} 20: 5 \mathrm{n}-3+\mathrm{C} 22: 5 \mathrm{n}-3+\mathrm{C} 22: 6 \mathrm{n}-3$.

${ }^{10} \Sigma \mathrm{n}-6=\mathrm{C} 18: 2 \mathrm{n}-6+\mathrm{C} 18: 3 \mathrm{n}-6+\mathrm{C} 20: 2 \mathrm{n}-6+\mathrm{C} 20: 3 \mathrm{n}-6+\mathrm{C} 20: 4 \mathrm{n}-6+\mathrm{C} 22: 2 \mathrm{n}-6+\mathrm{C} 22: 4 \mathrm{n}-6+\mathrm{C} 24: 2 \mathrm{n}-6$.

${ }^{11} \Sigma \mathrm{LA}+$ metabolites $=\mathrm{C} 18: 2 \mathrm{n}-6+\mathrm{C} 20: 2 \mathrm{n}-6+\mathrm{C} 22: 2 \mathrm{n}-6+\mathrm{C} 24: 2 \mathrm{n}-6$.

${ }^{12} \Sigma \mathrm{OA}+$ metabolites $=\Sigma$ cis n-9 MUFA + C16:2n-7 cis-6, cis-9.

${ }^{13}$ In total, $49 \mathrm{FA}$ were determined and summed. 
Table 3. Effect of trans-vaccenic acid supplementation on fatty acid (FA) composition of cultured ruminal epithelial cells; results shown as medians with quartile (Q) 1 and Q3 in brackets

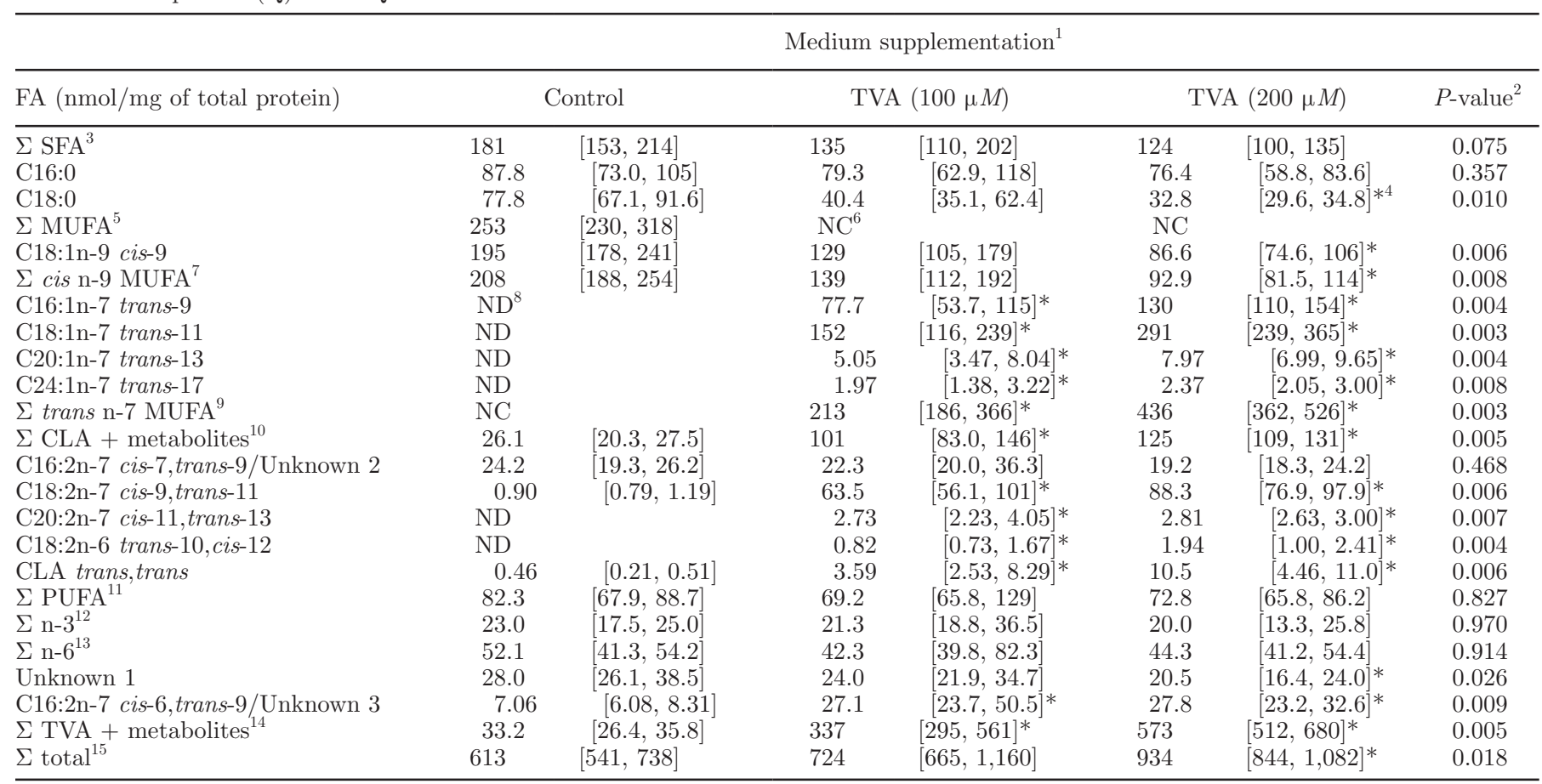

${ }^{1}$ Medium of cultured ruminal epithelial cells was supplemented with 100 or $200 \mu M$ trans-vaccenic acid (TVA).

${ }^{2}$ Kruskal-Wallis test was performed to identify differences between the medians of the differently supplemented groups $(\mathrm{N}=5) ; P<0.05$ was considered significant.

${ }^{3} \Sigma \mathrm{SFA}=\mathrm{C} 14: 0+\mathrm{C} 16: 0+\mathrm{C} 18: 0+\mathrm{C} 20: 0+\mathrm{C} 22: 0+\mathrm{C} 24: 0$.

${ }^{4}$ Mann-Whitney U test with Bonferroni correction was performed to identify the potential differences between the supplemented groups and the control group when the Kruskal-Wallis test indicated significant differences; ${ }^{*} P<0.025$ was considered significant.

${ }^{5} \Sigma$ MUFA $=\Sigma$ cis n-9 MUFA $+\Sigma$ trans n-7 MUFA.

${ }^{6} \mathrm{NC}=$ not calculated.

${ }^{7} \Sigma$ cis n-9 MUFA $=18: 1 \mathrm{n}-9+20: 1 \mathrm{n}-9+22: 1 \mathrm{n}-9+24: 1 \mathrm{n}-9$.

${ }^{8} \mathrm{ND}=$ not detectable; concentrations were $<0.05 \mathrm{nmol} / \mathrm{mg}$ of total protein.

${ }^{9} \Sigma$ trans $\mathrm{n}-7$ MUFA $=\mathrm{C} 16: 1 \mathrm{n}-7+\mathrm{C} 18: 1 \mathrm{n}-7+\mathrm{C} 20: 1 \mathrm{n}-7+\mathrm{C} 22: 1 \mathrm{n}-11$.

${ }^{10} \Sigma$ CLA + metabolites $=$ C16:2n-7 + CLA cis-9, trans-11 + C20:2n-7 + CLA trans-10, cis-12 + CLA trans,trans.

${ }^{11} \Sigma$ PUFA $=$ C16:4n-1 + C20:3n-9 + C22:2n-9 + $\Sigma$ n-3 + $\Sigma$ n- 6.

${ }^{12} \Sigma \mathrm{n}-3=\mathrm{C} 18: 3 \mathrm{n}-3+\mathrm{C} 20: 3 \mathrm{n}-3+\mathrm{C} 20: 5 \mathrm{n}-3+\mathrm{C} 22: 5 \mathrm{n}-3+\mathrm{C} 22: 6 \mathrm{n}-3$.

${ }^{13} \Sigma \mathrm{n}-6=\mathrm{C} 18: 2 \mathrm{n}-6+\mathrm{C} 18: 3 \mathrm{n}-6+\mathrm{C} 20: 2 \mathrm{n}-6+\mathrm{C} 20: 3 \mathrm{n}-6+\mathrm{C} 20: 4 \mathrm{n}-6+\mathrm{C} 22: 2 \mathrm{n}-6+\mathrm{C} 22: 4 \mathrm{n}-6+24: 2 \mathrm{n}-6$.

${ }^{14} \Sigma$ TVA + metabolites $=\Sigma$ trans $\mathrm{n}-7$ MUFA $+\Sigma$ CLA + metabolites + C16:2n-7 cis-6, trans-9.

${ }^{15}$ In total, 49 FA were determined and summed.

derived from the observation that addition of TVA at 100 and $200 \mu M$ led to a concentration-dependent increase in the amount of c9t11 (Figure 1). In control cells, only $0.90 \mathrm{nmol}$ of c $9 \mathrm{t} 11 / \mathrm{mg}$ of total protein was detected compared with 63.5 or $88.3 \mathrm{nmol}$ of c9t11/mg of total protein in TVA-treated cells. After TVA treatment, the amount of c9t11 was only slightly lower than that in cells exposed to $100 \mu M$ c9t11 directly (63.5 and $88.3 \mathrm{nmol}$ of c $9 \mathrm{t} 11 / \mathrm{mg}$ of total protein in 100 and $200 \mu M$ TVA-treated cells, respectively, compared with $110.4 \mathrm{nmol}$ of c9t11/mg of total protein in cells treated with $100 \mu M \mathrm{c} 9 \mathrm{t} 11)$.

\section{Effects of CLA, LA, OA, and TVA on mRNA Expression of SCD in REC and Corresponding Changes in SCDI}

All FA applied induced significant effects on $S C D$ mRNA expression (Figure 2). Compared with the untreated control, mRNA expression of $S C D$ was decreased after treatment with each FA $(P<0.01)$. The extent of downregulation ranged from 2-fold after TVA treatment to 5.3-fold after t10c12 and LA treatments. In line with these results, we found a decrease in SCDI16 and SCDI-18 compared with that of the control af- 


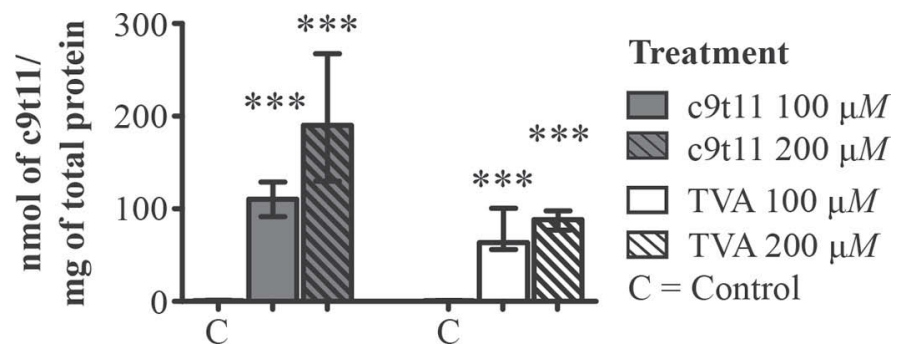

Figure 1. Accumulation of CLA cis-9,trans-11 (c9t11) in cultured ruminal epithelial cells treated with either CLA c9t11 or trans-vaccenic acid (TVA) at 100 or $200 \mu M$ for $48 \mathrm{~h}$. Cells treated with equivalent amounts of ethanol served as the control. The amount of CLA c9t11 is presented as the median with an interquartile range of $\mathrm{N}=5$ animals (in $\mathrm{nmol} / \mathrm{mg}$ of total protein). The asterisks indicate significant differences compared with the control value, which is close to zero and therefore not visible in the figure $\left({ }^{* * *} P<0.001\right.$; Mann-Whitney U-test).

ter each FA treatment except for treatment with TVA (panels A and B in Figure 3). Both CLA isomers added to the medium reduced SCDI-16 by approximately $40 \%$ $(P<0.001)$ and SCDI-18 by approximately $50 \%(P$ $<0.001)$ relative to the control. Exposure of the cells to LA led to a $58 \%$ reduction of SCDI-16 $(P<0.001)$ and a $65 \%$ reduction of SCDI-18 $(P<0.001)$ compared with their controls. Reduction of SCDI-16 caused by OA addition was similar to the alterations observed after CLA addition. We found no difference in SCDI-18 between control and TVA treatment $(P=0.57)$, but the result has to be seen in context with the effect of TVA treatment in EI. Whereas EI was not altered after CLA, LA, and OA treatment (data not shown), a difference between control and TVA treatment $(P<$ 0.001) could be detected (Figure $3 \mathrm{C}$ ).

\section{Effects of CLA, LA, OA, and TVA on MRNA Expression of MCT1 and MCT4 in REC}

To evaluate the effect of the applied FA on MCT1 and MCT4, we analyzed their mRNA levels. Regarding MCT1, we observed a difference in mRNA expression between control and CLA-treated cells (Figure 2). Expression of MCT1 was upregulated 1.2- and 1.3-fold by CLA c9t11 and t10c12, respectively, compared with their controls. Supplementing TVA likewise caused an upregulation of MCT1 mRNA expression (1.4-fold, $P=$ $0.03)$. Linoleic acid increased MCT1 mRNA level 1.4fold $(P=0.04)$. The slight nominal increase of $M C T 1$ mRNA expression induced by OA was not significant $(P=0.08$ compared with control). Expression of MCT4 was also significantly upregulated in REC after treatment with CLA c9t11, and CLA t10c12 tended to increase the mRNA level $(P=0.06)$. In REC treated with c9t11, we detected a 1.4-fold increase of MCT4
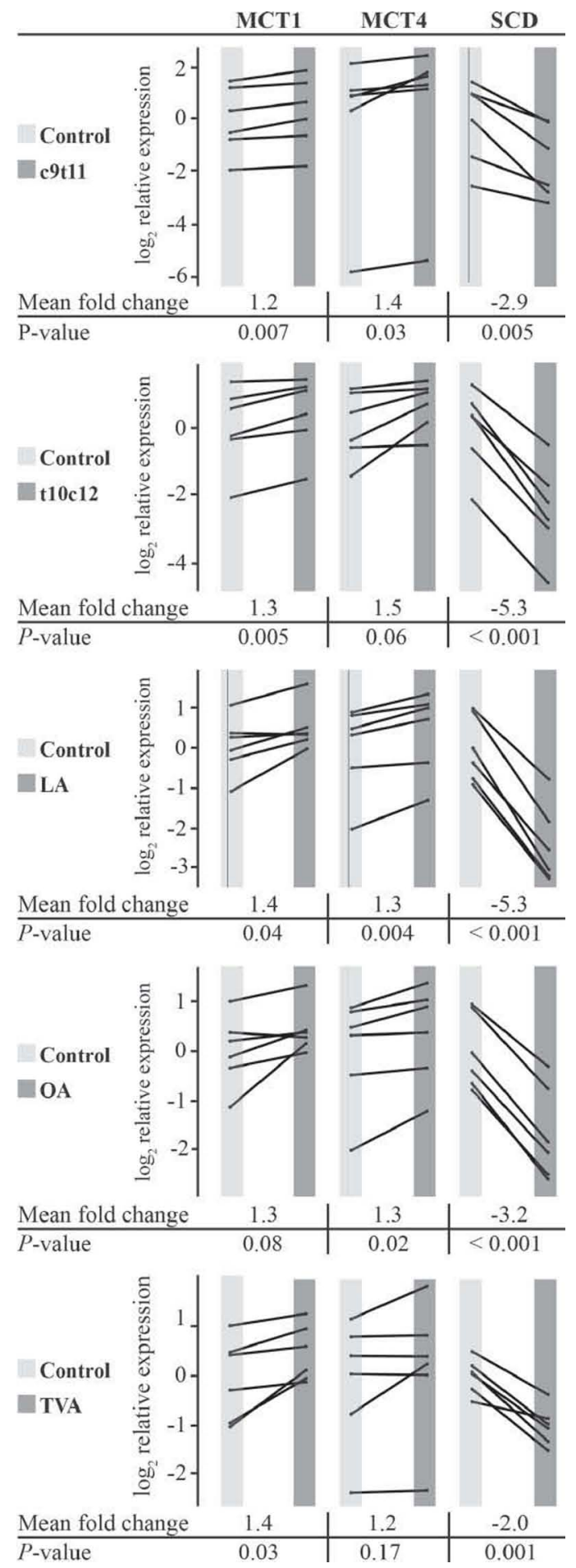

Figure 2. Relative mRNA expression of monocarboxylate transporter $(M C T) 1, M C T 4$, and stearoyl-CoA desaturase $(S C D)$ from cultured ruminal epithelial cells treated with CLA cis-9,trans-11 (c9t11), CLA trans-10,cis-12 (t10c12), linoleic acid (LA), oleic acid (OA), or trans-vaccenic acid (TVA) for $48 \mathrm{~h}$. The mRNA expression values $\left(\log _{2}\right.$ transformed) are expressed relative to the calibrator sample. Each graph represents the treatment effect within one animal; GAPDH and $\mathrm{Na}^{+} / \mathrm{K}^{+}$-ATPase subunit $\alpha-1$ were used as reference genes. The mean fold change is calculated compared with control $(\mathrm{N}=6) . P<0.05$ was considered significant (multilevel regression analysis). 
mRNA $(P=0.03)$; LA and OA likewise increased $M C T 4$ mRNA expression (1.3-fold both, $P=0.004$ and $P=0.02$ respectively). Exposure to TVA had no influence on $M C T 4$ mRNA expression in REC $(P=0.17)$.

\section{Effects of c9t11 in the Presence and Absence of PPARa and PPARY Antagonists}

To explore the involvement of PPAR $\alpha$ and PPAR $\gamma$ in the action of c9t11 on mRNA expression of MCT1, $M C T 4$, and $S C D$, cells were treated with or without selective PPAR $\alpha$ antagonist GW6471 and PPAR $\gamma$ antagonist GW9662 for $4 \mathrm{~h}$ before treatment with 100 $\mu M$ c9t11. The c9t11-induced downregulation of $S C D$ mRNA as shown in Figure 2 was further enhanced by pretreatment with the PPAR $\alpha$ antagonist GW6471 $(P<0.001$; Figure 4), indicating that activation of PPAR $\alpha$ might attenuate the depressive effect of c9t11 on $S C D$ mRNA expression. Antagonizing PPAR $\gamma$ by GW9662 also decreased the $S C D$ mRNA level $(P=$ 0.04 ) but only 1.5 -fold compared with 5.5-fold with PPAR $\alpha$ antagonist.

Expression of MCT4 also indicated that PPAR $\alpha$ at least partially attenuates the activation of other pathways induced by CLA. The enhanced mRNA expression of MCT4 already observed after c9t11 treatment was further enhanced after antagonizing PPAR $\alpha$ with GW $6471(P=0.047)$. Pretreatment with GW9662, the PPAR $\gamma$ antagonist, had no effect on MCT4 mRNA expression $(P=0.44)$. The $\mathrm{c} 9$ t11-induced upregulation of MCT1 mRNA expression decreased (1.4-fold) after treatment with either the PPAR $\alpha$ or PPAR $\gamma$ antagonist $(P=0.04$ for both $)$.

\section{DISCUSSION}

\section{Accumulation and Metabolization of CLA and Structurally Similar FA}

Medium supplementation with CLA, LA, OA, and TVA induced remarkable changes in the FA composition of cultured REC. After exposure, all supplemented FA were not only increased in REC but also metabolized by the cells. From the data shown in Tables 1-3, we could clearly identify the metabolites of each supplemented FA. The predominant metabolites we detected in our cells were products of $\beta$-oxidation (C16:1 and $\mathrm{C} 16: 2)$ and elongation (C20:1 and $\mathrm{C} 20: 2, \mathrm{C} 22: 1$ and C22:2). A similar metabolic pattern (i.e., $\beta$-oxidation and elongation) after CLA treatment was found in microsomal fractions from mouse liver and cultivated macrophages (Park et al., 2005) as well as vascular
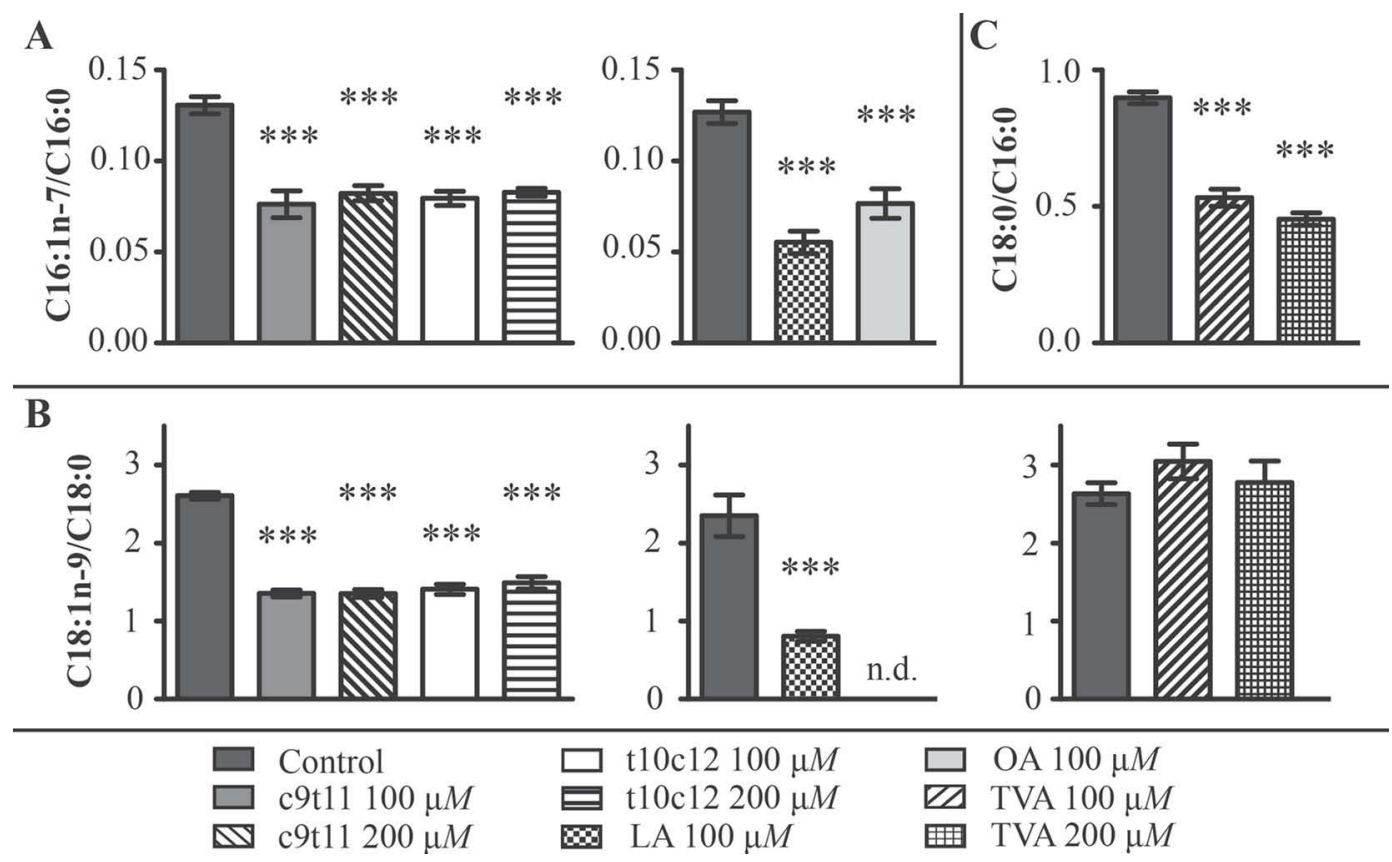

Figure 3. (A) Stearoyl-CoA desaturase (SCD) index assessed as 16:1n-7/C16:0 (SCDI-16) of untreated cells (control) versus cells treated with CLA cis-9,trans-11 (c9t11), CLA trans-10,cis-12 (t10c12), linoleic acid (LA), oleic acid (OA), or trans-vaccenic acid (TVA) for 48 h. (B) SCD index assessed as 18:1n-9/C18:0 (SCDI-18) of control versus cells treated with CLA c9t11, CLA t10c12, LA, OA and TVA. (C) Elongation index (EI) assessed as C18:0/C16:0 of untreated cells versus TVA treated cells. In all panels, indices are shown as the mean \pm SEM of $\mathrm{N}=5$ animals. The asterisks indicate significant differences compared with the control (*** $P<0.001 ;$ ANOVA and Tukey test; n.d. $=$ not determined). 
smooth muscle cells (Müller et al., 2005) and various leukemia cells (Agatha et al., 2004). Thus, CLA seem to be metabolized by the same metabolic pathways in REC as in other cells.

In comparing CLA and LA, they seem to be largely degraded to the same products. Oleic acid and TVA are also primarily metabolized by $\beta$-oxidation and elongation. Additionally, OA and TVA and their metabolites (i.e., MUFA) may serve as substrates for desaturases. We identified C16:2n-7 cis-7,cis-9 as an SCD product of C16:1n-9 cis-7 ( $\beta$-oxidation product of OA; Table 2 ) and $\mathrm{C} 16: 2 \mathrm{n}-7$ cis-6,trans- 9 as a $\Delta^{6}$-desaturase product of C16:1n-7 trans-9 ( $\beta$-oxidation product of TVA; Table $3)$. The most important metabolite of SCD-mediated desaturation (Corl et al., 2001) in TVA-treated cells was c9t11. Rumen epithelial cells are therefore able to produce CLA endogenously (Figure 1), similar to Caco-2 cells (Reynolds et al., 2008), bovine adipocytes (Kadegowda et al., 2013), and bovine and human mammary epithelium (Griinari et al., 2000; Mosley et al., 2006).

The CLA metabolites in cultured REC treated with 100 or $200 \mu M$ CLA are important for evaluating the biological effects of CLA. Park et al. (2005) showed that the CLA metabolites C20:2n-7 cis-11,trans-13 and C20:2n-6 trans-12,cis-14 alter heparin-releasable lipoprotein lipase activity as well as lipid accumulation in 3T3-L1 adipocytes. These metabolites were found in REC after CLA administration. We can therefore assume that REC functionality is altered in a similar way not only by the CLA tested but also by their metabolites. Furthermore, not only the administered CLA may exert alterations but also the endogenously synthesized c9t11 built from TVA by SCD.

\section{Alteration of SCD mRNA Level and Desaturation Indices}

As shown in Figure 2, mRNA expression of $S C D$ was significantly downregulated after $48 \mathrm{~h}$ of treatment with CLA, LA, OA, or TVA. This is in accordance with studies in bovine mammary epithelial cells (Kadegowda et al., 2009). The changes in mRNA expression were probably followed by an alteration of SCD abundance or activity. Results of FA analysis and index calculation provide evidence for this assumption. Both CLA isomers as well as LA led to a decreased amount of C16:1 cis-9 and OA (Tables 1 and 2). As a result, the calculated SCDI-16 and SCDI-18 were decreased (panels A and B in Figure 3). In contrast to CLA, LA, and OA treatments (where the decreased SCD indices coincided with decreased $S C D$ mRNA levels), TVA treatment decreased $S C D$ mRNA expression (Figure 2) but seemed to have no effect on SCDI (Figure 3B). This contradiction may be explained by the observation that TVA treatment also altered other metabolic pathways, whereas CLA, LA, and OA did not exert this effect. Additional TVA-induced alterations may be derived from the calculation of EI, which very likely reflects FA elongase 6 (ELOVL-6) pathway. Elongase 6 is responsible for the elongation of C16:0 to C18:0 in mammals (Leonard et al., 2004) and is known to be co-regulated with SCD (Wang et al., 2006). Whereas EI was unchanged in cell cultures treated with CLA, LA, and OA (data not shown), it was significantly reduced in the TVA-treated cells compared with that of the control (Figure 3C). Resulting from the decreased EI, the amount of C18:0 (i.e., the substrate of SCD) was also diminished. Consequently, we can assume that the

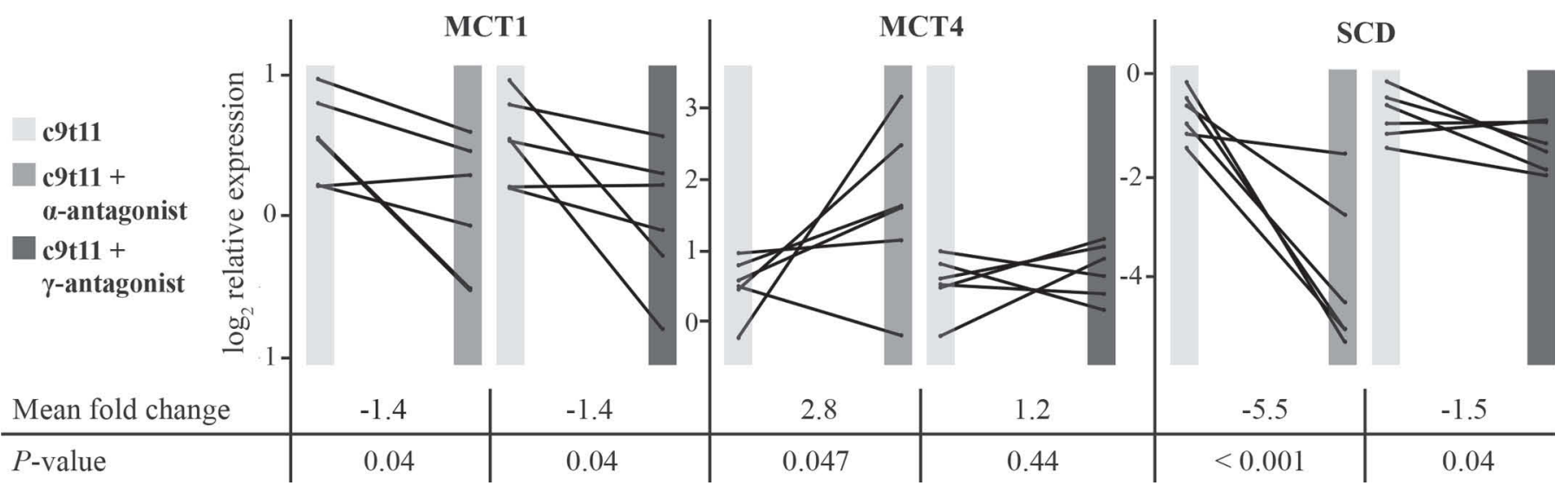

Figure 4. Relative mRNA expression of monocarboxylate transporter $(M C T)$ 1, MCT4, and stearoyl-CoA desaturase $(S C D)$ on cultured ruminal epithelial cells treated with CLA cis-9,trans-11 (c9t11) alone for $48 \mathrm{~h}$ or in combination with peroxisome proliferator-activated receptor $(\mathrm{PPAR}) \alpha\left(\alpha\right.$-antagonist) or PPAR $\gamma$ antagonist ( $\gamma$-antagonist). The mRNA expression values $\left(\log _{2}\right.$ transformed) are expressed relative to the calibrator sample. Each graph represents the treatment effect within one animal; GAPDH and $\mathrm{Na}^{+} / \mathrm{K}^{+}$-ATPase subunit $\alpha-1$ were used as reference genes. The mean fold change is calculated compared with c9t11 treatment $(\mathrm{N}=6) . P<0.05$ was considered significant (multilevel regression analysis). 
reduction of SCDI-18 after TVA was disguised by the reduced amount of C18:0.

Still, we cannot definitely determine whether TVA itself was able to directly manipulate SCD or whether this was due to the c9t11 formed endogenously from TVA, as shown in Figure 1. It has been shown in bovine mammary epithelial cells that TVA exposure initially increased $S C D$ mRNA expression (Jin et al., 2012). However, later during TVA exposure, $S C D$ mRNA expression was decreased, potentially due to the endogenously produced c9t11 (Jin et al., 2012). In our study, TVA treatment of REC lasted for $48 \mathrm{~h}$, suggesting that we could not detect an initial effect of TVA exposure but instead detected the subsequent effect of the endogenously formed c9t11.

As outlined above, the downregulation of $S C D$ mRNA expression and the accompanying changes in SCDI-16 and SCDI-18 support the suggestion that activity of SCD is decreased by exposure of the cells to c9t11, t10c12, LA, OA, and TVA. However, the conclusions derived from the indices or from the amounts of FA in general must be drawn carefully. We cannot exclude influences other than endogenous production of FA. The amount of FA in the cells may also have been influenced by release of FA out of the cells. Measurement of SCD activity should be the subject of further investigation to clarify the de facto regulation mechanism of SCD in REC. Nevertheless, similar to findings in human aortic smooth muscle cells (Minville-Walz et al., 2012), porcine subcutaneous adipose tissue (Smith et al., 2002), mouse liver (Lee et al., 1998), and H2.35 liver cells (Choi et al., 2000), our study shows that CLA, as well as other FA including LA, OA, and TVA, may have a depressive effect on SCD in REC at least on mRNA level if applied for a longer time.

Regarding the supposed functional consequences of altered SCD activity, the enzyme is known to play a direct role in regulating lipid and energy metabolism of the cell (Flowers and Ntambi, 2008) as well as an indirect role on inflammation and stress (Liu et al., 2011) due to its control of MUFA production, in particular, C16:1n-7 cis-9 and OA. Apart from being a component of lipids, MUFA serve as mediators of signal transduction and cell differentiation (Miyazaki and Ntambi, 2003; Igal, 2010). In this way, CLA may indirectly modulate the morphology of rumen epithelium if applied for a longer amount of time.

\section{Changes in MCT1 and MCT4 mRNA Expression}

As shown in Figure 2, the upregulating effects on the mRNA expression of MCT1 and (partially) MCT4 expression were not specific for CLA but could have been caused, at least partially, by their precursors.
Monocarboxylate transporter 1 is of prominent interest because of its role as a transport protein involved in the handling of short-chain FA, of their metabolites, such as $\beta$-hydroxybutyrate, acetoacetate, and lactate, and in the $\mathrm{pH}$ homeostasis of the cell (Gäbel et al., 2002; Müller et al., 2002). Thus, any CLA-induced changes of MCT1 activity might influence, directly and indirectly, the transfer of metabolites. The role of MCT4 is still under discussion (Kirat et al., 2007; Dengler et al., 2015).

\section{Role of PPARa and PPARY}

We focused on PPAR $\alpha$ - and PPAR $\gamma$-dependent pathways because CLA are known to interfere with these transcription factors (Moya-Camarena et al., 1999; Benjamin et al., 2013). The c9t11-induced upregulation of MCT1 mRNA expression (Figures 2 and 4) could be suspended by both the PPAR $\alpha$ and PPAR $\gamma$ antagonists. Similar to Benesch et al. (2014), we thus demonstrated that MCT1 mRNA expression is upregulated by PPAR $\alpha$. However, PPAR $\gamma$ seems to act similarly on $M C T 1$ in REC.

We showed that antagonizing PPAR $\alpha$ enhanced the stimulating effect of c9t11 on MCT4 (Figure 4). Thus, the addition of the PPAR $\alpha$ antagonist seems to have revealed a suppressing effect of PPAR $\alpha$ triggered by c9t11. Consequently, c9t11 action in REC probably includes both a PPAR $\alpha$-dependent suppressing effect on MCT4 mRNA expression as well as an upregulating effect initiated by other regulatory pathways. It is known that MCT4 is upregulated by hypoxia-inducible factor (HIF) $1 \alpha$ (Ullah et al., 2006; Rosafio and Pellerin, 2014). According to Yamasaki et al. (2012) and Zhang and Li (2012), HIF $1 \alpha$ may also be activated by CLA and is therefore a possible pathway for the CLA-induced upregulation of MCT4. Although tissue and species differences within the regulation of $M C T$ mRNA may be assumed (Cheng et al., 2012; Thomas et al., 2012), our data may give further hints on the regulation pathways of $M C T$ triggered by CLA. Regarding $S C D$, application of the PPAR $\alpha$ and PPAR $\gamma$ antagonist enhanced the c9t11-induced decrease of $S C D$ mRNA expression. Thus, similar to the action of c9t11 on MCT4 mRNA expression, the action of c9t11 on $S C D$ included both an upregulating and downregulating component. In contrast to c9t11 action on MCT4 mRNA expression, however, the upregulating, and not the downregulating, component seems to be mediated by PPAR $\alpha$ and PPAR $\gamma$. Therefore, we can conclude that PPAR $\alpha$ and PPAR $\gamma$ mediate the upregulation of $S C D$ mRNA expression in REC. However, the observed downregulation of $S C D$ mRNA expression after c9t11 treatment (Figures 2 and 4) indicates that pathways 
other than PPAR $\alpha$ and PPAR $\gamma$ are simultaneously activated by CLA.

\section{Considerations of CLA Availability in the Rumen}

The described metabolic effects of CLA and of structurally similar FA observed have to be seen in the context of their use as feed additives. Taking into account the low duodenal availability of rumen-protected CLA after oral uptake (Pappritz et al., 2011), we have to assume that the rumen epithelium may be exposed to high amounts of CLA and TVA under certain feeding conditions.

Unfortunately, measurements of free CLA in the rumen fluid after CLA administration are not available. However, the amount of CLA accruing in the rumen per day after oral administration of CLA can be roughly calculated from the feeding instructions (e.g., Lutrell Combi, BASF SE, Ludwigshafen, Germany). Assuming a CLA administration of $125 \mathrm{~g} / \mathrm{d}$ fed in 2 rations including $10 \%$ c9t11 and t10c12 (e.g., Lutrell Combi), a protection rate against biohydrogenation (depending on protection method) of up to $40 \%$ according to Pappritz et al. (2011), and a rumen fluid volume of $100 \mathrm{~L}$ according to Owens and Goetsch (1988), the initial concentration of CLA in the ruminal liquid may increase to $37.5 \mathrm{mg} / \mathrm{L}(133.9 \mu M)$ of an isomer after feeding. Thus, compared with the initial concentrations of 0 to $0.8 \mathrm{mg} / \mathrm{L}$ of CLA in the rumen content of cows fed CLA-free diets (Troegeler-Meynadier et al., 2006), diets supplemented with $125 \mathrm{~g}$ of CLA per day in 2 rations of $75 \mathrm{~g}$ each may result in approximately 50-fold-higher concentrations of CLA isomers in the rumen per feeding, and thus reach the range of CLA concentrations used in our experiments (100 and $200 \mu M$ ).

\section{CONCLUSIONS}

Our study, as well as previous studies, showed that 50 to $150 \mu \mathrm{M}$ FA supplemented to the culture medium is sufficient to induce remarkable changes concerning the functionality of cells. Additionally, we showed that the absorbed CLA act as signaling molecules and may influence various signaling pathways. However, structurally similar FA were able to induce comparable changes, indicating that various FA, not only CLA, may influence the function of REC when ingested. Furthermore, whether the alterations of epithelial function induced by CLA and structurally similar FA are detrimental to, beneficial to, or do not affect the whole animal cannot be determined at present and must be the subject of future investigations.

\section{ACKNOWLEDGMENTS}

The authors gratefully appreciate Dirk K. Wissenbach (Department of Metabolomics, Helmholtz-Centre for Environmental Research Leipzig, Germany) for the assistance in GC-MS analysis. Special thanks to Gabriele Dobeleit (Institute of Physiological Chemistry, Faculty of Veterinary Medicine, University of Leipzig, Germany) for her excellent technical assistance in performing and analyzing the GC data and Ines Urbansky (Institute of Veterinary Physiology, Faculty of Veterinary Medicine, University of Leipzig, Germany) for her excellent technical assistance at cell culture and PCR. This work was supported by the H. Wilhelm Schaumann Stiftung (Hamburg, Germany).

\section{REFERENCES}

Agatha, G., A. Voigt, E. Kauf, and F. Zintl. 2004. Conjugated linoleic acid modulation of cell membrane in leukemia cells. Cancer Lett. 209:87-103. http://dx.doi.org/10.1016/j.canlet.2003.11.022.

Altschul, S. F., T. L. Madden, A. A. Schäffer, J. Zhang, Z. Zhang, W. Miller, and D. J. Lipman. 1997. Gapped BLAST and PSI-BLAST: A new generation of protein database search programs. Nucleic Acids Res. 25:3389-3402. http://dx.doi.org/10.1093/nar/25.17.3389.

Bates, D., M. Maechler, and B. Bolker. 2012. lme4: Linear mixedeffects models using S4 ( $\mathrm{R}$ package version 0.999999-0). Accessed Oct. 8, 2015. http://CRAN.R-project.org/package=lme4.

Bauman, D. E., J. W. Perfield 2nd, K. J. Harvatine, and L. H. Baumgard. 2008. Regulation of fat synthesis by conjugated linoleic acid: Lactation and the ruminant model. J. Nutr. 138:403-409.

Benesch, F., F. Dengler, F. Masur, H. Pfannkuche, and G. Gäbel. 2014. Monocarboxylate transporters 1 and 4: Expression and regulation by PPAR $\alpha$ in ovine ruminal epithelial cells. Am. J. Physiol. Regul. Integr. Comp. Physiol. 307:R1428-R1437. http://dx.doi. org/10.1152/ajpregu.00408.2013.

Benjamin, S., S. Flotho, T. Börchers, and F. Spener. 2013. Conjugated linoleic acid isomers and their precursor fatty acids regulate peroxisome proliferator-activated receptor subtypes and major peroxisome proliferator responsive element-bearing target genes in HepG2 cell model. J. Zhejiang Univ. Sci. B 14:115-123. http:// dx.doi.org/10.1631/jzus.B1200175.

Benjamin, S., T. Hanhoff, T. Börchers, and F. Spener. 2005. An improved molecular test system for the screening of human PPAR transactivation by conjugated linoleic acid isomers and their precursor fatty acids. Eur. J. Lipid Sci. Technol. 107:706-715. http:// dx.doi.org/10.1002/ejlt.200401041.

Bhattacharya, A., J. Banu, M. Rahman, J. Causey, and G. Fernandes. 2006. Biological effects of conjugated linoleic acids in health and disease. J. Nutr. Biochem. 17:789-810. http://dx.doi. org/10.1016/j.jnutbio.2006.02.009

Cedernaes, J., J. Alsiö, A. Västermark, U. Riserus, and H. B. Schiöth. 2013. Adipose tissue stearoyl-CoA desaturase 1 index is increased and linoleic acid is decreased in obesity-prone rats fed a highfat diet. Lipids Health Dis. 12:2. http://dx.doi.org/10.1186/1476$511 \mathrm{X}-12-2$.

Cheng, C., N. F. Edin, K. H. Lauritzen, I. Aspmodal, S. Christoffersen, L. Jian, L. J. Rasmussen, E. O. Pettersen, G. Xiaoqun, and L. H. Bergersen. 2012. Alterations of monocarboxylate transporter densities during hypoxia in brain and breast tumour cells. Cell Oncol. (Dordr.) 35:217-227. http://dx.doi.org/10.1007/s13402012-0081-9.

Chin, S. F., W. Liu, J. M. Storkson, Y. L. Ha, and M. W. Pariza. 1992. Dietary sources of conjugated dienoic isomers of linoleic acid, a 
newly recognized class of anticarcinogens. J. Food Compos. Anal. 5:185-197. http://dx.doi.org/10.1016/0889-1575(92)90037-K.

Choi, Y., Y. C. Kim, Y. B. Han, Y. Park, M. W. Pariza, and J. M. Ntambi. 2000. The trans-10, cis-12 isomer of conjugated linoleic acid downregulates stearoyl-CoA desaturase 1 gene expression in 3T3-L1 adipocytes. J. Nutr. 130:1920-1924.

Choi, Y., Y. Park, M. W. Pariza, and J. M. Ntambi. 2001. Regulation of stearoyl-CoA desaturase activity by the trans-10, cis-12 isomer of conjugated linoleic acid in HepG2 cells. Biochem. Biophys. Res. Commun. 284:689-693. http://dx.doi.org/10.1006/bbrc.2001.5036.

Choi, Y., Y. Park, J. M. Storkson, M. W. Pariza, and J. M. Ntambi 2002. Inhibition of stearoyl-CoA desaturase activity by the cis9,trans-11 isomer and the trans-10,cis-12 isomer of conjugated linoleic acid in MDA-MB-231 and MCF-7 human breast cancer cells. Biochem. Biophys. Res. Commun. 294:785-790. http://dx.doi. org/10.1016/S0006-291X(02)00554-5.

Corl, B. A., L. H. Baumgard, D. A. Dwyer, J. M. Griinari, B. S. Phillips, and D. E. Bauman. 2001. The role of delta(9)-desaturase in the production of cis-9, trans-11 CLA. J. Nutr. Biochem. 12:622-630.

Dengler, F., R. Rackwitz, F. Benesch, H. Pfannkuche, and G. Gäbel. 2014. Bicarbonate-dependent transport of acetate and butyrate across the basolateral membrane of sheep rumen epithelium. Acta Physiol. (Oxf.) 210:403-414. http://dx.doi.org/10.1111/ apha. 12155 .

Dengler, F., R. Rackwitz, F. Benesch, H. Pfannkuche, and G. Gäbel. 2015. Both butyrate incubation and hypoxia upregulate genes involved in the ruminal transport of SCFA and their metabolites. J. Anim. Physiol. Anim. Nutr. (Berl.) 99:379-390. http://dx.doi. org/10.1111/jpn.12201

Eder, K., and R. Ringseis. 2010. Metabolism and actions of conjugated linoleic acids on atherosclerosis-related events in vascular endothelial cells and smooth muscle cells. Mol. Nutr. Food Res. 54:17-36. http://dx.doi.org/10.1002/mnfr.200900042

Flowers, M. T., and J. M. Ntambi. 2008. Role of stearoyl-coenzyme A desaturase in regulating lipid metabolism. Curr. Opin. Lipidol. 19:248-256. http://dx.doi.org/10.1097/MOL.0b013e3282f9b54d.

Gäbel, G., J. R. Aschenbach, and F. Müller. 2002. Transfer of energy substrates across the ruminal epithelium: Implications and limitations. Anim. Health Res. Rev. 3:15-30. http://dx.doi.org/10.1079/ AHRR200237.

Gálfi, P., S. Neogrady, and F. Kutas. 1981. Culture of epithelial cells from bovine ruminal mucosa. Vet. Res. Commun. 4:295-300.

Graham, C., I. Gatherar, I. Haslam, M. Glanville, and N. L. Simmons. 2007. Expression and localization of monocarboxylate transporters and sodium/proton exchangers in bovine rumen epithelium. Am. J. Physiol. Regul. Integr. Comp. Physiol. 292:R997-R1007. http:// dx.doi.org/10.1152/ajpregu.00343.2006.

Griinari, J. M., B. A. Corl, S. H. Lacy, P. Y. Chouinard, K. V. Nurmela, and D. E. Bauman. 2000. Conjugated linoleic acid is synthesized endogenously in lactating dairy cows by delta(9)-desaturase. J. Nutr. 130:2285-2291.

Harfoot, C. G., and G. P. Hazlewood. 1997. Lipid metabolism in the rumen. Pages 382-426 in The Rumen Microbial Ecosystem. P. N. Hobson and C. S. Stewart, ed. Chapman \& Hall, London, UK.

Hox, J. J. 2010. Multilevel Analysis: Techniques and Applications. 2nd ed. Routledge, New York, NY.

Igal, R. A. 2010. Stearoyl-CoA desaturase-1: A novel key player in the mechanisms of cell proliferation, programmed cell death and transformation to cancer. Carcinogenesis 31:1509-1515. http://dx.doi. org/10.1093/carcin/bgq131.

Jin, Y. C., Z. H. Li, Z. S. Hong, C. X. Xu, J. A. Han, S. H. Choi, J. L. Yin, Q. K. Zhang, K. B. Lee, S. K. Kang, M. K. Song, Y. J. Kim, H. S. Kang, Y. J. Choi, and H. G. Lee. 2012. Conjugated linoleic acid synthesis-related protein proteasome subunit alpha 5 (PSMA5) is increased by vaccenic acid treatment in goat mammary tissue. J. Dairy Sci. 95:4286-4297. http://dx.doi.org/10.3168/ jds.2011-4281.

Kadegowda, A. K. G., M. Bionaz, L. S. Piperova, R. A. Erdman, and J. J. Loor. 2009. Peroxisome proliferator-activated receptorgamma activation and long-chain fatty acids alter lipogenic gene networks in bovine mammary epithelial cells to various extents. J. Dairy Sci. 92:4276-4289. http://dx.doi.org/10.3168/jds.2008-1932.

Kadegowda, A. K. G., T. A. Burns, M. C. Miller, and S. K. Duckett. 2013. Cis-9, trans-11 conjugated linoleic acid is endogenously synthesized from palmitelaidic (C16:1 trans-9) acid in bovine adipocytes. J. Anim. Sci. 91:1614-1623. http://dx.doi.org/10.2527/ jas.2012-5590.

Kirat, D., Y. Matsuda, N. Yamashiki, H. Hayashi, and S. Kato. 2007. Expression, cellular localization, and functional role of monocarboxylate transporter 4 (MCT4) in the gastrointestinal tract of ruminants. Gene 391:140-149. http://dx.doi.org/10.1016/j. gene.2006.12.020.

Kitchen, R. R., M. Kubista, and A. Tichopad. 2010. Statistical aspects of quantitative real-time PCR experiment design. Methods 50:231-236. http://dx.doi.org/10.1016/j.ymeth.2010.01.025.

König, B., A. Koch, K. Giggel, B. Dordschbal, K. Eder, and G. I. Stangl. 2008. Monocarboxylate transporter (MCT)-1 is up-regulated by PPARalpha. Biochim. Biophys. Acta 1780:899-904. http://dx.doi. org/10.1016/j.bbagen.2008.03.002.

Lee, K. N., M. W. Pariza, and J. M. Ntambi. 1998. Conjugated linoleic acid decreases hepatic stearoyl-CoA desaturase mRNA expression. Biochem. Biophys. Res. Commun. 248:817-821. http://dx.doi. org/10.1006/bbrc.1998.8994.

Leesnitzer, L. M., D. J. Parks, R. K. Bledsoe, J. E. Cobb, J. L. Collins, T. G. Consler, R. G. Davis, E. A. Hull-Ryde, J. M. Lenhard, L. Patel, K. D. Plunket, J. L. Shenk, J. B. Stimmel, C. Therapontos, T. M. Willson, and S. G. Blanchard. 2002. Functional consequences of cysteine modification in the ligand binding sites of peroxisome proliferator activated receptors by GW9662. Biochemistry 41:6640-6650. http://dx.doi.org/10.1021/bi0159581.

Leonard, A. E., S. L. Pereira, H. Sprecher, and Y.-S. Huang. 2004. Elongation of long-chain fatty acids. Prog. Lipid Res. 43:36-54. http://dx.doi.org/10.1016/S0163-7827(03)00040-7.

Liu, X., M. S. Strable, and J. M. Ntambi. 2011. Stearoyl CoA desaturase 1: Role in cellular inflammation and stress. Adv. Nutr. 2:15-22. http://dx.doi.org/10.3945/an.110.000125.

Minville-Walz, M., J. Gresti, L. Pichon, S. Bellenger, J. Bellenger, M. Narce, and M. Rialland. 2012. Distinct regulation of stearoyl-CoA desaturase 1 gene expression by cis and trans C18:1 fatty acids in human aortic smooth muscle cells. Genes Nutr. 7:209-216. http:// dx.doi.org/10.1007/s12263-011-0258-2.

Miyazaki, M., and J. M. Ntambi. 2003. Role of stearoyl-coenzyme A desaturase in lipid metabolism. Prostaglandins Leukot. Essent. Fatty Acids 68:113-121. http://dx.doi.org/10.1016/S09523278(02)00261-2.

Mosley, E. E., M. K. McGuire, J. E. Williams, and M. A. McGuire. 2006. Cis-9, trans-11 conjugated linoleic acid is synthesized from vaccenic acid in lactating women. J. Nutr. 136:2297-2301.

Moya-Camarena, S. Y., J. P. Vanden Heuvel, S. G. Blanchard, L. A Leesnitzer, and M. A. Belury. 1999. Conjugated linoleic acid is a potent naturally occurring ligand and activator of PPARalpha. J. Lipid Res. 40:1426-1433.

Müller, A., R. Ringseis, K. Düsterloh, S. Gahler, K. Eder, and H. Steinhart. 2005. Detection of conjugated dienoic fatty acids in human vascular smooth muscle cells treated with conjugated linoleic acid. Biochim. Biophys. Acta 1737:145-151. http://dx.doi. org/10.1016/j.bbalip.2005.09.011.

Müller, F., J. R. Aschenbach, and G. Gäbel. 2000. Role of $\mathrm{Na}^{+} / \mathrm{H}^{+}$ exchange and $\mathrm{HCO}_{3}{ }^{-}$transport in pHi recovery from intracellular acid load in cultured epithelial cells of sheep rumen. J. Comp. Physiol. B Biochem. Syst. Environ. Physiol. 170:337-343.

Müller, F., K. Huber, H. Pfannkuche, J. R. Aschenbach, G. Breves, and G. Gäbel. 2002. Transport of ketone bodies and lactate in the sheep ruminal epithelium by monocarboxylate transporter 1 . Am. J. Physiol. Gastrointest. Liver Physiol. 283:G1139-G1146. http:// dx.doi.org/10.1152/ajpgi.00268.2001.

Murphy, E. F., G. J. Hooiveld, M. Müller, R. A. Calogero, and K. D. Cashman. 2007. Conjugated linoleic acid alters global gene expression in human intestinal-like Caco-2 cells in an isomer-specific manner. J. Nutr. 137:2359-2365. 
Odens, L. J., R. Burgos, M. Innocenti, M. J. VanBaale, and L. H. Baumgard. 2007. Effects of varying doses of supplemental conjugated linoleic acid on production and energetic variables during the transition period. J. Dairy Sci. 90:293-305. http://dx.doi. org/10.3168/jds.S0022-0302(07)72630-9.

Owens, F. N., and A. L. Goetsch. 1988. Ruminal Fermentation. Pages 145-171 in The Ruminant Animal: Digestive Physiology and Nutrition. D. C. Church, ed. Prentice Hall, Upper Saddle River, NJ.

Pappritz, J., P. Lebzien, U. Meyer, G. Jahreis, R. Kramer, G. Flachowsky, and S. Dänicke. 2011. Duodenal availability of conjugated linoleic acids after supplementation to dairy cow diets. Eur. J. Lipid Sci. Technol. 113:1443-1455. http://dx.doi.org/10.1002/ ejlt.201100170.

Park, Y., J. M. Storkson, K. J. Albright, W. Liu, and M. W. Pariza. 2005. Biological activities of conjugated fatty acids: Conjugated eicosadienoic (conj. 20:2delta (c11,t13/t12,c14)), eicosatrienoic (conj. 20:3delta (c8,t12,c14)), and heneicosadienoic (conj. 21:2delta $(\mathrm{c} 12, \mathrm{t} 14 / \mathrm{c} 13, \mathrm{t} 15))$ acids and other metabolites of conjugated linoleic acid. Biochim. Biophys. Acta 1687:120-129. http://dx.doi. org/10.1016/j.bbalip.2004.11.010.

Parodi, P. W. 1997. Cows' milk fat components as potential anticarcinogenic agents. J. Nutr. 127:1055-1060.

Peter, A., A. Cegan, S. Wagner, R. Lehmann, N. Stefan, A. Königsrainer, I. Königsrainer, H.-U. Häring, and E. Schleicher. 2009. Hepatic lipid composition and stearoyl-coenzyme A desaturase 1 mRNA expression can be estimated from plasma VLDL fatty acid ratios. Clin. Chem. 55:2113-2120. http://dx.doi.org/10.1373/ clinchem.2009.127274.

Pfaffl, M. W., G. W. Horgan, and L. Dempfle. 2002. Relative expression software tool (REST) for group-wise comparison and statistical analysis of relative expression results in real-time PCR. Nucleic Acids Res. 30:e36 http://dx.doi.org/10.1093/nar/30.9.e36.

Reynolds, C. M., C. E. Loscher, A. P. Moloney, and H. M. Roche. 2008. Cis-9, trans-11-conjugated linoleic acid but not its precursor trans-vaccenic acid attenuate inflammatory markers in the human colonic epithelial cell line Caco-2. Br. J. Nutr. 100:13-17. http:// dx.doi.org/10.1017/S0007114508894329.

Ringseis, R., A. Müller, K. Düsterloh, S. Schleser, K. Eder, and H. Steinhart. 2006. Formation of conjugated linoleic acid metabolites in human vascular endothelial cells. Biochim. Biophys. Acta 1761:377-383. http://dx.doi.org/10.1016/j.bbalip.2006.02.005.

Roche, H. M., A. M. Terres, I. B. Black, M. J. Gibney, and D. Kelleher. 2001. Fatty acids and epithelial permeability: effect of conjugated linoleic acid in Caco-2 cells. Gut 48:797-802. http://dx.doi. org/10.1136/gut.48.6.797.

Rosafio, K., and L. Pellerin. 2014. Oxygen tension controls the expression of the monocarboxylate transporter MCT4 in cultured mouse cortical astrocytes via a hypoxia-inducible factor- $1 \alpha-$ mediated transcriptional regulation. Glia 62:477-490. http:// dx.doi.org/10.1002/glia.22618.

Salas-Salvadó, J., F. Marquez-Sandoval, and M. Bullo. 2006. Conjugated linoleic acid intake in humans: A systematic review focusing on its effect on body composition, glucose, and lipid metabolism. Crit. Rev. Food Sci. Nutr. 46:479-488. http://dx.doi. org/10.1080/10408390600723953.

Seidel, A., T. Gück, and H. Fuhrmann. 2005. The influence of longchain polyunsaturated fatty acids on total lipid fatty acid compo- sition of a canine mastocytoma cell line. J. Vet. Med. A Physiol. Pathol. Clin. Med. 52:219-224. http://dx.doi.org/10.1111/j.14390442.2005.00711.x.

Smith, P. K., R. I. Krohn, G. T. Hermanson, A. K. Mallia, F. H. Gartner, M. D. Provenzano, E. K. Fujimoto, N. M. Goeke, B. J. Olson, and D. C. Klenk. 1985. Measurement of protein using bicinchoninic acid. Anal. Biochem. 150:76-85. http://dx.doi. org/10.1016/0003-2697(85)90442-7.

Smith, S. B., T. S. Hively, G. M. Cortese, J. J. Han, K. Y. Chung, P. Castenada, C. D. Gilbert, V. L. Adams, and H. J. Mersmann. 2002. Conjugated linoleic acid depresses the delta9 desaturase index and stearoyl coenzyme A desaturase enzyme activity in porcine subcutaneous adipose tissue. J. Anim. Sci. 80:2110-2115.

Sönnichsen, M., and B. W. Müller. 1999. A rapid and quantitative method for total fatty acid analysis of fungi and other biological samples. Lipids 34:1347-1349.

Thomas, C., D. J. Bishop, K. Lambert, J. Mercier, and G. A. Brooks. 2012. Effects of acute and chronic exercise on sarcolemmal MCT1 and MCT4 contents in human skeletal muscles: Current status. Am. J. Physiol. Regul. Integr. Comp. Physiol. 302:R1-R14. http://dx.doi.org/10.1152/ajpregu.00250.2011.

Troegeler-Meynadier, A., L. Bret-Bennis, and F. Enjalbert. 2006. Rates and efficiencies of reactions of ruminal biohydrogenation of linoleic acid according to $\mathrm{pH}$ and polyunsaturated fatty acids concentrations. Reprod. Nutr. Dev. 46:713-724. http://dx.doi. org/10.1051/rnd:2006046.

Ullah, M. S., A. J. Davies, and A. P. Halestrap. 2006. The plasma membrane lactate transporter MCT4, but not MCT1, is up-regulated by hypoxia through a HIF-1alpha-dependent mechanism. J. Biol. Chem. 281:9030-9037. http://dx.doi.org/10.1074/jbc. M511397200.

Wang, Y., D. Botolin, J. Xu, B. Christian, E. Mitchell, B. Jayaprakasam, M. G. Nair, J. M. Peters, J. V. Busik, L. K. Olson, and D. B. Jump. 2006. Regulation of hepatic fatty acid elongase and desaturase expression in diabetes and obesity. J. Lipid Res. 47:2028-2041. http://dx.doi.org/10.1194/jlr.M600177-JLR200.

Xu, H. E., T. B. Stanley, V. G. Montana, M. H. Lambert, B. G. Shearer, J. E. Cobb, D. D. McKee, C. M. Galardi, K. D. Plunket, R. T. Nolte, D. J. Parks, J. T. Moore, S. A. Kliewer, T. M. Willson, and J. B. Stimmel. 2002. Structural basis for antagonist-mediated recruitment of nuclear co-repressors by PPARalpha. Nature 415:813-817. http://dx.doi.org/10.1038/415813a.

Yamasaki, M., T. Nagatomo, T. Matsuyama, Y. Ikeho, E. Kato, K. Nishiyama, Y. Sakakibara, M. Suiko, and K. Nishiyama. 2012. Conjugated linoleic acids inhibit hypoxia inducible factor-1 $\alpha$ stabilization under hypoxic condition in human hepatocellular carcinoma cells. J. Oleo Sci. 61:491-496. http://dx.doi.org/10.5650/ jos.61.491.

Ye, J., G. Coulouris, I. Zaretskaya, I. Cutcutache, S. Rozen, and T. L. Madden. 2012. Primer-BLAST: A tool to design target-specific primers for polymerase chain reaction. BMC Bioinformatics 13:134 http://dx.doi.org/10.1186/1471-2105-13-134.

Zhang, J., and D. Li. 2012. Effect of conjugated linoleic acid on inhibition of prolyl hydroxylase 1 in hearts of mice. Lipids Health Dis. 11:22 http://dx.doi.org/10.1186/1476-511X-11-22. 